\title{
Assessment of Bone Marrow Biopsy and Cytogenetic Findings in Patients with Multiple Myeloma
}

\author{
Multipl Myelomlu Hastalarda Kemik Iliği Biyopsisi ve Sitogenetik Bulguların \\ Değerlendirilmesi
}

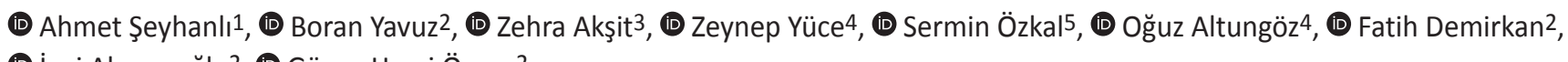
(D) Inci Alacacıŏlu22, (D) Güner Hayri Özsan²

1 Sivas Numune Hospital, Clinic of Hematology, Sivas, Turkey

${ }^{2}$ Dokuz Eylül University Faculty of Medicine, Department of Hematology, Izmir, Turkey

${ }^{3}$ Dokuz Eylül University Faculty of Medicine, Department of Internal Medicine, Izmir, Turkey

${ }^{4}$ Dokuz Eylül University Faculty of Medicine, Department of Medical Biology, Izmir, Turkey

${ }^{5}$ Dokuz Eylül University Faculty of Medicine, Department of Pathology, izmir, Turkey

\section{Abstract}

Objective: Multiple myeloma (MM) is a malignant condition characterized by the accumulation of malignant plasma cells. Although MM remains incurable, the survival of MM patients has improved considerably due to the application of autologous stem cell transplantation, novel agents, and advanced treatment strategies. This study aimed to determine the cytogenetic characterization and bone marrow (BM) features of Turkish patients with MM.

Materials and Methods: Eighty-five MM patients were admitted to Dokuz Eylül University Hospital in Turkey. BM samples of these MM patients were subjected to cytogenetic analyses at diagnosis and during therapy as a part of therapeutical and clinical evaluation. A complete cytogenetic study was performed using the G-banding technique. Fluorescence in situ hybridization (FISH) analysis was performed using cytoplasmic immunoglobulin. The degree of BM fibrosis was determined using reticulin histochemical staining. We determined the percentage of BM plasma cells based on the extent of CD38 staining.

Results: Eighty-five MM patients were retrospectively identified between 2015 and 2021. The median age was 63 (38-90) years. Of the 85 patients, $60(70.6 \%)$ were male and $25(29.4 \%)$ were female. Seventy-two (84.7\%) cases had BM fibrosis at the time of diagnosis. The most common was grade 2 fibrosis, recorded in 35 cases (41.2\%). About $72.9 \%$ of the patients showed more than 50\% plasma cells. FISH analysis indicated the presence of abnormal chromosomes in $37 \%(32 / 85)$ of the patients. The most frequent abnormality was Immunoglobulin heavy-chain (IGH) translocation (21.3\%).

Conclusion: Subgroup analysis of IGH mutations is crucial in the identification of high-risk MM patients. We believe that our study will contribute to the determination of BM biopsy and cytogenetic features of MM patients in our country.

Keywords: Multiple myeloma, Bone marrow biopsy, Cytogenetic analysis, Fluorescence in situ hybridization

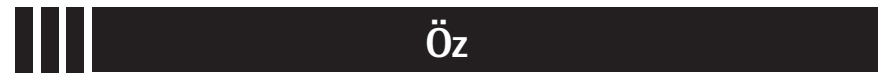

Amaç: Multipl myelom (MM), malign plazma hücrelerinin birikmesi ile karakterize malign bir durumdur. MM tam kür sağlamanan hastalık olmasa da, uygulanan otolog kök hücre nakli ve yeni ilaçlar ve yeni tedavi stratejileri nedeniyle MM hastalarının sağkalımı önemli ölçüde gelişmiştir. Bu çalışmada MM'li Türk hastalarda sitogenetik karakterizasyon ve kemik iliği (KI) özelliklerinin belirlenmesi amaçlanmıştır.

Gereç ve Yöntemler: Türkiye'deki Dokuz Eylül Üniversite Hastanesi'ndeki 85 MM hastasını kaydettik. Bu MM hastalarının kemik iliği örneklerinde, tedavi ve klinik değerlendirmenin bir parçası olarak tanı anında ve tedavi süresince sitogenetik analiz yapıldı. G-bantlama tekniği kullanılarak tam bir sitogenetik çalışma gerçekleştirildi. Fazlar arası Floresan in situ hibridizasyon (FISH) analizi, sitoplazmik immünoglobulin ile yapıldı. Kemik iliği fibrozunun derecesi, retikülinin histokimyasal boyası kullanılarak belirlendi. Ki plazma hücrelerinin yüzdesi, CD38 boyamasınına göre belirlendi.

Bulgular: 2015 ve 2021 yılları arasında geriye dönük olarak 85 MM hastası belirlendi. Ortanca yaş 63 (38-90) yıldı. Seksen beş hastanın 60'ı $(\% 70,6)$ erkek, 25'i $(\% 29,4)$ kadındı. Tanı anında kemik iliği fibrozu 72 olguda $(\% 84,7)$ mevcuttu. En sık 35 hastada $(\% 41,2)$ derece 2 fibrozis görüldü. Hastaların $\% 72,9^{\prime}$ unda plazma hücre yüzdeleri \%50'den fazlaydı. FISH analizi sonuçlarında kromozom anomalilerinin varlığı \%37 (32/85) oranındadır. En sık kromozom görülen anormallik IGH translokasyonuydu $(\% 21,3)$.

Sonuç: IGH mutasyonlarının alt grup analizi, yüksek riskli MM hastalarının belirlenmesinde kritik öneme sahiptir. Çalışmamızın ülkemizdeki MM hastalarının Ki biyopsisi ve sitogenetik özelliklerinin belirlenmesine katkı sağlayacağına inanıyoruz.

Anahtar Sözcükler: Multipl myelom, Kemik iliği biyopsisi, Sitogenetik analiz, Floresan in situ hibridizasyon

${ }^{\circ}$ Copyright 2022 by Turkish Society of Hematology

Turkish Journal of Hematology, Published by Galenos Publishing House

口 Address for Correspondence/Yazışma Adresi: Ahmet Şeyhanlı, M.D., Sivas Numune Hospital, Clinic of Hematology,

Received/Geliş tarihi: May 22, 2021 


\section{Introduction}

Multiple myeloma (MM) is a malignant condition characterized by the accumulation of malignant plasma cells. It is the second most common hematological malignancy that develops in the bone marrow (BM) [1]. Although MM remains incurable, the survival of MM patients has improved considerably due to the application of autologous stem cell transplantation (ASCT), novel agents, and advanced treatment strategies. However, this development has not been uniform. The existing heterogeneity is dependent on patient-specific factors such as age, comorbidities, and disease-related factors, including cytogenetic and molecular features, BM fibrosis (BMF), and the plasma cells in the BM. Several risk classifications have been made for personalized therapeutic approaches. A clinical staging system for MM was first developed by Durie and Salmon [2] in 1975. The International Staging System (ISS) score was then defined by Greipp et al. [3] in 2005 based on two parameters: serum $\beta 2$-microglobulin level and serum albumin. Avet-Loiseau et al. [4] and Cavo-Rosinol et al. [5] combined cytogenetics with the ISS to improve risk stratification. Several techniques are available to detect genetic abnormalities in MM. Karyotyping is applied to detect cytogenetic abnormalities and abnormalities dependent on the proliferative index of malignant plasma cells but provides limited information in vitro due to the low proliferative ability of malignant plasma cells [6]. Kishimoto et al. [7]reported that abnormal karyotypes are seen in approximately $30 \%-50 \%$ of MM cases. The gold-standard approach for the detection of genomic abnormalities in MM is fluorescence in situ hybridization (FISH), which has been implemented and validated by various cytogenetic laboratories around the globe [8]. The identification of high-risk subtypes of myeloma is vital. According to previous works, high-risk MM patients showed a $20 \%-50 \%$ reduction in overall survival (OS) compared to standard-risk patient groups when undergoing induction with conventional chemotherapy followed by ASCT. The present study aimed to determine the cytogenetic characters and BM features of Turkish patients with MM.

\section{Materials and Methods}

From January 2015 to January 2021, 85 MM patients were admitted to Dokuz Eylül University Hospital in Turkey. BM samples of these MM patients were subjected to cytogenetic analyses at diagnosis and during therapy as a part of therapeutical and clinical evaluation. Conventional cytogenetic analysis was performed for all samples at presentation and after a short-term culture period of 24/72 h. Cells were treated with colcemid and harvested for $20 \mathrm{~min}$. Karyotypes were then analyzed using the standard G-banding technique. A minimum of 20 metaphases per case were analyzed. The karyotypes were reported according to the 2016 International System for Human Cytogenetic
Nomenclature. An interphase FISH study was performed on BM samples according to the relevant manufacturer's hybridization and post-hybridization stringency conditions with minimal modifications. Dual-color CytoCell FISH probes specific to loci 13q14.3 (LPH006), CKS1B (1q21-22)/CDKN2C (1p32.3) (LPH039), IGH (14q32.33) (Break-apart, LPH 014), P53 (17p13.1)/ATM (11q32) (LPH 052), and MLL (11q23.3) (Break-apart, LPH 013) were used. Threshold values of copy number gain, deletion, and break-apart positivity were $7 \%, 7 \%$, and $10 \%$, respectively. FISH slides were analyzed with a motorized Olympus BX61 fluorescence microscope equipped with 4',6-diamidino2-phenylindole, fluorescein isothiocyanate, rhodamine, dual, and triple band-pass filters (Chroma, Bellows Falls, VT, USA). Two independent observers analyzed the slides blindly, enumerating at least 200 optimally hybridized nuclei. The degree of BMF was detected using reticulin histochemical staining. The level of fibrosis as determined by a pathologist was scored according to the guidelines of the World Health Organization [grade 0: no fibrosis, grade 1 (mild): low (fine reticulin network), grade 2 (moderate): intermediate (multifocal or diffuse non-confluent fibrosis), grade 3 (severe): high (marked and diffuse fibrosis)]. The percentage of BM plasma cells was determined based on the extent of CD38 staining and categorized as Group $1(<20 \%)$, Group 2 (20\%-50\%), or Group 3 (>50\% plasma cells). The ISS was used based on the combination of serum $\beta 2$-microglobulin and serum albumin.

\section{Statistical Analysis}

IBM SPSS Statistics 24.0 for Windows (IBM Corp., Armonk, NY, USA) was used for statistical analysis. Numerical variables are presented as median or mean, while categorical variables are given as number ( $\mathrm{n}$ ) and percentage (\%). The OS curves were estimated using the Kaplan-Meier method whereby OS was defined as the time from the diagnosis of MM to death from any cause. The confidence interval was determined as $95 \%$ in the analyses and values of $p<0.05$ were considered to be statistically significant.

\section{Results}

Eighty-five MM patients were retrospectively identified between 2015 and 2021. The median age was 63 (38-90) years and 56.5\% of the patients were under 65 years old. Of the 85 patients, 60 (70.6\%) were male and 25 (29.4\%) were female. Bone lesions were detected in $57.6 \%$ of these cases, anemia in $42.4 \%$, impaired renal function in $27.1 \%$, and hypercalcemia in $18.8 \%$. Most patients were in ISS stage III. More than half of the patients received proteasome inhibitor-based therapy for induction. Information about the induction therapy of five patients could not be obtained. Further details about the demographic, laboratory, and clinical characteristics are presented in Table 1. 


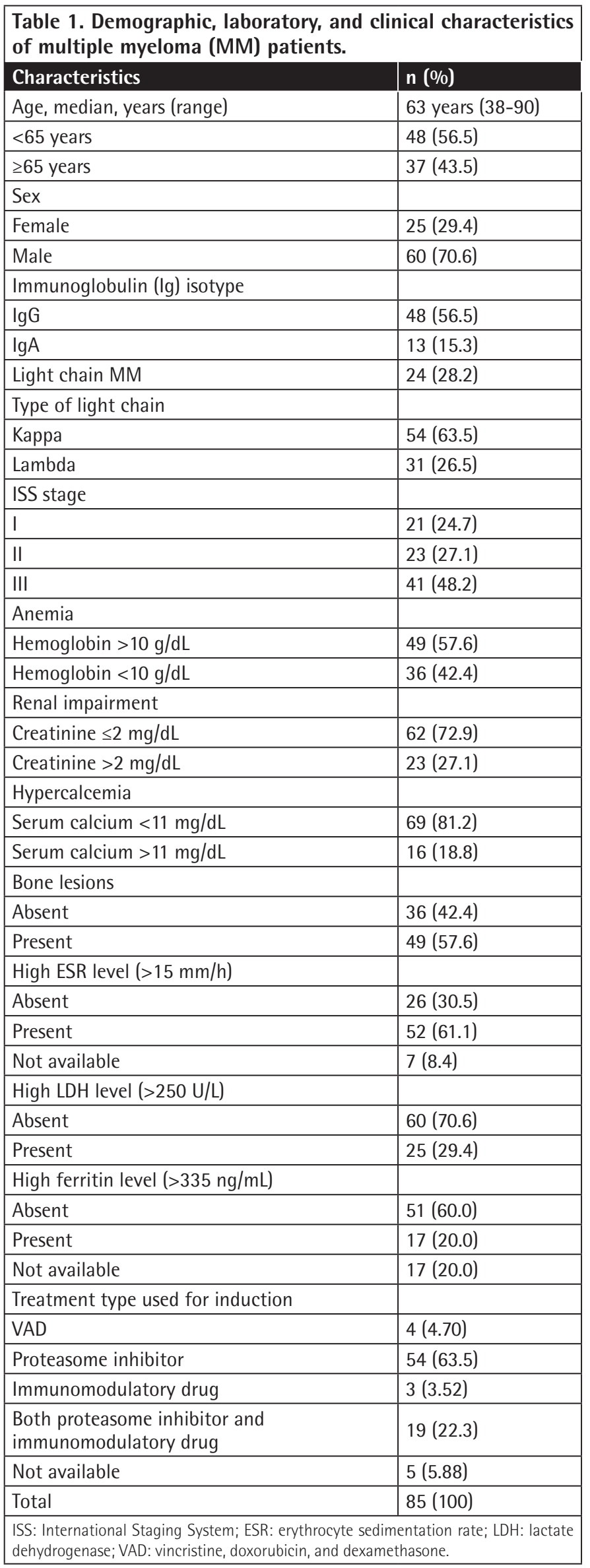

BMF was observed at the time of diagnosis in 72 cases (84.7\%). The most common finding was grade 2 fibrosis in 35 patients (41.2\%). In $72.9 \%$ of the patients, a plasma cell percentage of over $50 \%$ was observed, and the most common type of plasma cell infiltration was the diffuse involvement pattern (50.6\%). Based on FISH analysis, 37\% (32/85) of cases showed the presence of chromosomal anomalies. The most frequent abnormality was the IGH translocation (21.3\%). Based on karyotype analysis, $54.4 \%(37 / 68)$ of the patients had normal karyotypes while $5.8 \%(4 / 68)$ had abnormal karyotypes. Table 2 presents plasma cell percentages, plasma cell infiltration patterns, and fibrosis results from BM biopsy samples. Detailed cytogenetic results of these MM patients are presented in Table 3.

In this study, the median OS of the entire population was 29.4 months (Figure 1a). Del(17p13)-negative patients had longer OS compared to del(17p13)-positive patients (32.4 months vs. 11.1 months, $p=0.015$ ) (Figure 1b).

IGH-negative and del(13q)-negative patients had longer OS compared to IGH-positive and del(13q)-positive patients. However, this was not statistically significant ( $p=0.594$ and $p=0.094$, respectively). A lower percentage of plasma cells in the BM was associated with better OS than higher plasma cell percentages. The median OS was 42.6 months in patients with 0\%-19\% plasma cells, 33.5 months in patients with 20\%-49\% plasma cells, and 28.4 months in patients with 50\%-100\% plasma cells. However, this observation was not statistically significant $(p=0.969)$. The results of multivariate analysis adjusting for the del(17p13) mutation, IGH mutation, del(13) mutation, BMF, plasma cell infiltration pattern, and plasma cell percentage are shown in Table 4.

Table 2. Analysis of plasma cell percentage, plasma cell infiltration pattern, and fibrosis in bone marrow biopsy samples from patients with multiple myeloma at diagnosis.

Bone marrow plasma cell percentage (\%) $\mathrm{n} \mathrm{( \% )}$

\begin{tabular}{|l|l|}
\hline $0-19$ & $5(5.9)$ \\
\hline $20-49$ & $62(72.9)$ \\
\hline $50-100$ & \\
\hline Pattern of plasma cell infiltration & $33(38.8)$ \\
\hline Interstitial & $9(10.6)$ \\
\hline Nodular & \\
\hline Diffuse & $43(50.6)$ \\
\hline Bone marrow fibrosis & \\
\hline MF-0 & $13(15.3)$ \\
\hline MF-1 & $35(41.2)$ \\
\hline MF-2 & $9(10.6)$ \\
\hline MF-3 & \\
\hline Total & $85(100)$ \\
\hline MF: Marrow fibrosis. & \\
\hline &
\end{tabular}



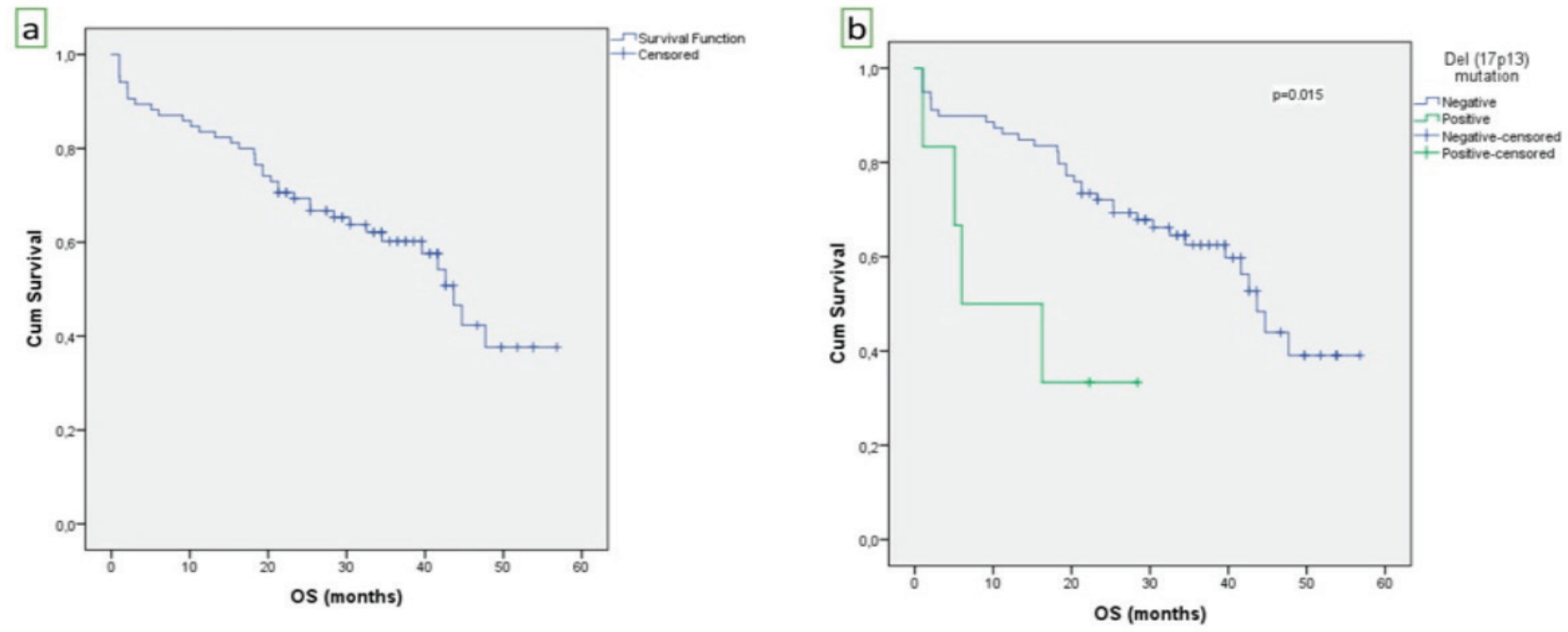

Figure 1. a) Kaplan-Meier curve of overall survival (OS) for the entire study cohort ( $n=85)$. The median OS was 29.4 months. b) Del(17p13)negative patients had longer OS compared to del(17p13)-positive patients (32.4 months vs. 11.1 months, $p=0.015)$.

Table 3. Detailed cytogenetic results of multiple myeloma patients.

\begin{tabular}{|l|l|l|}
\hline Characteristics & Information available, $\mathbf{n}$ & Positive patients, $\mathbf{n}(\%)$ \\
\hline Del(17p13) mutation & 85 & $6(7.1)$ \\
\hline Del(13q14) mutation & 49 & $9(18.4)$ \\
\hline IGH translocations & 80 & $17(21.3)$ \\
\hline CKS1B mutation & 1 & $0(0.00)$ \\
\hline MLL mutation & 15 & $0(0.00)$ \\
\hline Karyotyping & 68 & $37(54.4)$ \\
\hline Normal & & $2(2.9)$ \\
\hline Hyperdiploid & & $2(2.9)$ \\
\hline Non-hyperdiploid & & $27(39.7)$ \\
\hline Non-diagnostic & & \\
\hline
\end{tabular}

\section{Discussion}

MM remains an incurable malignancy with varying clinical and prognostic differences depending on various factors including age, comorbidity, cytogenetic and genomic features, and tumor microenvironment characteristics in the bone marrow. The disease incidence ranges from 5 to 7 per 100,000 and increases with age. The median age at diagnosis of MM is 69 years. Fewer than $14 \%$ of patients are younger than 55 years. MM is seen more often in men and African Americans. The etiological reasons behind these differences are not sufficiently understood. Survival among patients with MM ranges from 1 year to more than 10 years. Median survival in unselected patients with MM is 3 years. The 5 -year relative survival rate is $46.6 \%$ [9]. In our study, the median age was 63 and male patients constituted
$70.6 \%$ of the total. These findings are slightly different from those published in the literature, possibly due to environmental and genetic factors.

Understanding the alterations in the BM microenvironment and the molecular pathways related to these changes is crucial for the further improvement of MM treatment and the outcomes of these patients. Sailer et al. [10] demonstrated that characteristics of the tumor microenvironment such as plasma cell differentiation, volume of plasma cell infiltration, and infiltration pattern have predictive value. However, the prognostic efficacy of BMF at the time of diagnosis is still controversial [11,12]. Babarović et al. [13] reported that the 5 -year survival rates of patients with increased BMF subjected to post-treatment BM biopsy were significantly shorter than 


\begin{tabular}{|c|c|c|c|c|}
\hline Characteristics & Median OS (months) & Hazard ratio & $95 \% \mathrm{Cl}$ & $\mathbf{p}$ \\
\hline $\operatorname{Del}(17 p 13)$ & & & & 0.015 \\
\hline Del(17p13)-negative & 32.4 & 1 & & \\
\hline Del(17p13)-positive & 11.1 & 3.45 & $1.18-10.0$ & \\
\hline IGH-negative & 28.9 & 1 & & \\
\hline IGH-positive & 22.8 & 1.35 & $0.44-4.11$ & \\
\hline $\operatorname{Del}(13 q)$ mutation & & & & 0.094 \\
\hline Bone marrow fibrosis & & & & 0.938 \\
\hline MF-0 & 34.4 & 1 & & \\
\hline MF-1 & 33.0 & 0.90 & $0.35-2.29$ & \\
\hline MF-2 & 27.4 & 1.15 & $0.46-2.87$ & \\
\hline MF-3 & 33.4 & 1.08 & $0.31-3.72$ & \\
\hline Pattern of plasma cell infiltration & & & & 0.466 \\
\hline $20-49$ & 33.5 & 0.86 & $0.23-3.31$ & \\
\hline $50-100$ & 28.4 & 0.97 & $0.29-3.26$ & \\
\hline
\end{tabular}

those of patients without fibrosis. Thus, the assessment of BMF was concluded to have prognostic value in the follow-up of MM patients [13]. A recent study by Paul et al. [14] showed that the median progression-free survival in patients without BMF was 30.2 months, while in those with BMF, it was 21 months. On the other hand, median OS was 61.2 months and 45.1 months among patients without and with BMF, respectively. These findings were statistically significant [14]. Our results suggested that the pattern of plasma cell infiltration and the degree of fibrosis at diagnosis did not significantly influence survival times, possibly due to the relatively small groups in this study.

Several predictive models like the Durie and Salmon [2] staging system and the ISS have been used to categorize MM patients into risk groups. The Durie and Salmon [2] staging system was the first such system devised for MM and it has been widely used for several decades. Later proposed by Greipp et al. [3], the ISS became more widely used. The ISS is based on the prognostic factors of serum $\beta 2$-microglobulin and serum albumin. For ISS stages I, II, and III, the median survival of MM patients was determined to be 62 months, 44 months, and 29 months, respectively [3]. A major limitation of the ISS classification is that it does not consider patient-specific factors. Approximately half of our patients were in ISS stage III and their median OS was 28.4 months. Our results were thus consistent with the study of Greipp et al. [3]. Chromosomal abnormalities detected by FISH were combined with the ISS to improve risk stratification $[4,5]$. Because karyotypes are highly sensitive in the detection 
of numerical chromosomal abnormalities, patients can be classified into specific categories such as normal, hyperdiploid, or non-hyperdiploid (including hypodiploid, pseudodiploid, and near-tetraploid) karyotypes [15]. Among non-hyperdiploid cases of MM, the hypodiploid subtype is associated with poor prognosis $[16,17]$. In our study, abnormal karyotypes were detected in 4 of $68(5.8 \%)$ patients. Among these cases, non-hyperdiploid abnormalities were observed in two patients. However, chromosomal abnormalities could not be evaluated in $39.7 \%$ of the total cases because of the absence of metaphase cells. FISH does not require metaphase cells before analysis and it is accepted as the gold-standard test for the detection of genomic abnormalities in $\mathrm{MM}$, being applied and verified by cytogenetics laboratories around the globe [8]. Further studies are underway for identifying the optimal risk-based classification and treatment for MM and especially for the identification of high-risk MM patients. The International Myeloma Working Group provided a consensus decision stating that FISH panel testing should be performed for at least $\mathrm{t}(4 ; 14)$, $t(14 ; 16)$, and del(17p13) to define patients with high-risk disease [18]. In addition to that recommendation, Boyd et al. [19] suggested that FISH panel tests for $+1 \mathrm{q} 21$ and $t(14 ; 20)$ should be performed in MM risk classification. Deletion of chromosome $17 \mathrm{p} 13$ increases the immortalization of tumor cells by inhibiting apoptosis [20]. Del(17p13) is observed in about 10\% of MM cases and has been associated with impaired OS $[21,22,23,24]$. In our study, the incidence rate of the del(17p13) mutation was $7.1 \%$ and del(17p13)-negative patients had significantly longer OS compared to del(17p13)-positive patients (32.4 months vs. 11.1 months, respectively). Previously, del(13q) was in the poor prognosis group, but it is now excluded from risk stratification as it was detected in almost 50\% of myeloma patients and is thought to be secondary to the close association with $t(4 ; 14)$, del(17p) $[19,25,26]$. In this study, del(13q) was detected in 9 of 49 cases $(18.4 \%)$ and a significant adverse effect of del(13q) on OS was not observed ( $p=0.094)$.

Chromosome $14 q 32$ translocations (heavy chain IGH translocations) in MM also increase dysregulated proliferation and inhibit differentiation. Bergsagel and Kuehl [27] reported an incidence of IGH translocations of 60\%-65\% in intramedullary MM. However, in our study, the incidence of IGH mutations was lower (21.3\%). Over 20 different IGH translocations have been revealed, among which IGH translocations $\mathrm{t}(4 ; 14)$, $t(14 ; 16)$, and $t(14 ; 20)$ are associated with poor prognosis in $M M$ patients [28]. The use of proteasome inhibitor-based induction is recommended to improve the prognosis of patients with t $(4 ; 14)$ but not those with del(17p13) [29]. Unfortunately, our study does not include subgroup analysis of IGH mutations that involve several recurrent translocations. Recently, gene expression profiling methods, such as sequencing comparative genomic hybridization (CGH), single nucleotide polymorphism sequencing $\mathrm{CGH}$, gene expression profiling, and RNA sequencing have been introduced to identify patients with particularly high-risk MM $[30,31,32]$. However, this is not feasible in routine practice due to the high costs.

\section{Study Limitations}

The present study has a few limitations. It was a retrospective study based on single-center data. Possibly because of the small sample size, we did not observe a significant adverse effect of IGH mutation on OS. Since our study did not include subgroups of IGH mutations, high-risk patients could not be determined clearly.

\section{Conclusion}

To the best of our knowledge, this study is the first of its kind conducted in Turkey to include genetic results. This is especially crucial in the identification of high-risk myeloma subtypes. The subgroup analysis of IGH mutations is critical in identifying high-risk MM patients. IGH subgroup analyses have been conducted recently in our center. The present study will contribute to determining BM biopsy and cytogenetic features of MM patients in our country.

\section{Ethics}

Ethics Committee Approval: This study was approved by the Ethics Committee of Dokuz Eylül University (2021/10-25).

Informed Consent: Retrospective study.

\section{Authorship Contributions}

Concept: A.Ş., B.Y., Z.A., Z.Y., S.Ö., O.A., F.D., I.A., G.H.Ö.; Design: A.Ş., B.Y., Z.A., Z.Y., S.Ö., O.A., F.D., I.A., G.H.Ö.; Data Collection or Processing: A.Ş., B.Y., Z.A., Z.Y., S.Ö., O.A., F.D., I.A., G.H.Ö.; Analysis or Interpretation: A.Ş., B.Y., Z.A., Z.Y., S.Ö., O.A., F.D., I.A., G.H.Ö.; Literature Search: A.S.., B.Y., Z.A., Z.Y., S.Ö., O.A., F.D., I.A., G.H.Ö.; Writing: A.Ş., B.Y., Z.A., Z.Y., S.Ö., O.A., F.D., I.A., G.H.Ö.

Conflict of Interest: No conflict of interest was declared by the authors.

Financial Disclosure: The authors declared that this study received no financial support.

\section{References}

1. Kyle RA, Rajkumar SV. ASH 50th anniversary review. Blood 2008;111:29622972.

2. Durie BG, Salmon SE. A clinical staging system for multiple myeloma correlation of measured myeloma cell mass with presenting clinical features, response to treatment, and survival. Cancer 1975;36:842-854.

3. Greipp PR, San Miguel J, Durie BG, Crowley JJ, Barlogie B, Bladé J, Boccadoro M, Child JA, Avet-Loiseau H, Kyle RA, Lahuerta JJ, Ludwig H, Morgan G, Powles R, Shimizu K, Shustik C, Sonneveld P, Tosi P, Turesson I, Westin J. International staging system for multiple myeloma. J Clin Oncol $2005 ; 23: 3412-3420$. 
4. Avet-Loiseau H, Durie BG, Cavo M, Attal M, Gutierrez N, Haessler J, Goldschmidt H, Hajek R, Lee JH, Sezer O, Barlogie B, Crowley J, Fonseca R, Testoni N, Ross F, Rajkumar SV, Sonneveld P, Lahuerta J, Moreau P, Morgan $G$; International Myeloma Working Group. Combining fluorescent in situ hybridization data with ISS staging improves risk assessment in myeloma: an International Myeloma Working Group collaborative project. Leukemia 2013;27:711-717.

5. Cavo M, Salwender H, Rosiñol L, Moreau P, Petrucci MT, Blau IW, Bladé J, Attal M, Patriarca F, Weisel K, San Miguel JF, Avet-Loiseau H, Testoni N, Pfreundschuh M, Lahuerta JJ, Facon T, Pantani L, Scheid C, Gutierrez N, Marit G, Palumbo A, Martin ML, Caillot D, Goldschmidt H. Double vs single autologous stem cell transplantation after bortezomib-based induction regimens for multiple myeloma: an integrated analysis of patient-level data from phase European III studies. Blood 2013;122:767.

6. Avet-Loiseau H, Hulin C, Campion L, Rodon P, Marit G, Attal M, Royer B, Dib $M$, Voillat L, Bouscary D, Caillot D, Wetterwald M, Pegourie B, Lepeu G, Corront B, Karlin L, Stoppa AM, Fuzibet JG, Delbrel X, Guilhot F, Kolb B, Decaux O, Lamy T, Garderet L, Allangba O, Lifermann F, Anglaret B, Moreau $P$, Harousseau JL, Facon T. Chromosomal abnormalities are major prognostic factors in elderly patients with multiple myeloma: the Intergroupe Francophone du Myélome experience. J Clin Oncol 2013;31:2806-2809.

7. Kishimoto RK, Freitas SLWd, Ratis CA, Borri D, Sitnik R, Velloso EDRP. Validation of interphase fluorescence in situ hybridization (iFISH) for multiple myeloma using CD138 positive cells. Rev Bras Hematol Hemoter 2016;38:113-120.

8. Munshi NC, Anderson KC, Bergsagel PL, Shaughnessy J, Palumbo A, Durie B, Fonseca R, Stewart AK, Harousseau JL, Dimopoulos M, Jagannath S, Hajek R, Sezer O, Kyle R, Sonneveld P, Cavo M, Rajkumar SV, San Miguel J, Crowley J, Avet-Loiseau $\mathrm{H}_{\text {; International Myeloma Workshop Consensus Panel } 2 .}$ Consensus recommendations for risk stratification in multiple myeloma: report of the International Myeloma Workshop Consensus Panel 2. Blood 2011;117:4696-4700.

9. Morgan G, Davies F, Linet M. Myeloma aetiology and epidemiology. Biomed Pharmacother 2002;56:223-234.

10. Sailer M, Vykoupil KF, Peest D, Coldewey R, Deicher H, Georgii A. Prognostic relevance of a histologic classification system applied in bone marrow biopsies from patients with multiple myeloma: a histopathological evaluation of biopsies from 153 untreated patients. Eur J Haematol 1995;54:137-146.

11. Kuter DJ, Bain B, Mufti G, Bagg A, Hasserjian RP. Bone marrow fibrosis: pathophysiology and clinical significance of increased bone marrow stromal fibres. Br J Haematol 2007;139:351-362.

12. Tefferi A. Pathogenesis of myelofibrosis with myeloid metaplasia. J Clin Oncol 2005;23:8520-8530.

13. Babarović E, Valković T, Štifter S, Budisavljević I, Seili-Bekafigo I, DuletićNačinović $A$, Lučin $K$, Jonjić $N$. Assessment of bone marrow fibrosis and angiogenesis in monitoring patients with multiple myeloma. Am J Clin Pathol 2012;137:870-878.

14. Paul B, Zhao $Y$, Loitsch G, Feinberg D, Mathews P, Barak I, Dupuis M, Li $Z$, Rein L, Wang E, Kang $Y$. The impact of bone marrow fibrosis and JAK2 expression on clinical outcomes in patients with newly diagnosed multiple myeloma treated with immunomodulatory agents and/or proteasome inhibitors. Cancer Med 2020;9:5869-5880.

15. Fonseca R, Barlogie B, Bataille R, Bastard C, Bergsagel PL, Chesi M, Davies FE, Drach J, Greipp PR, Kirsch IR, Kuehl WM, Hernandez JM, Minvielle S, Pilarski LM, Shaughnessy JD Jr, Stewart AK, Avet-Loiseau H. Genetics and cytogenetics of multiple myeloma: a workshop report. Cancer Res 2004;64:1546-1558.

16. Smadja NV, Bastard C, Brigaudeau C, Leroux D, Fruchart C. Hypodiploidy is a major prognostic factor in multiple myeloma. Blood 2001;98:2229-2238.

17. Van Wier S, Braggio E, Baker A, Ahmann G, Levy J, Carpten JD, Fonseca R. Hypodiploid multiple myeloma is characterized by more aggressive molecular markers than non-hyperdiploid multiple myeloma. Haematologica 2013;98:1586-1592.

18. Fonseca R, Bergsagel PL, Drach J, Shaughnessy J, Gutierrez N, Stewart AK, Morgan G, Van Ness B, Chesi M, Minvielle S, Neri A, Barlogie B, KuehI WM, Liebisch P, Davies F, Chen-Kiang S, Durie BG, Carrasco R, Sezer O, Reiman T, Pilarski L, Avet-Loiseau H; International Myeloma Working Group. International Myeloma Working Group molecular classification of multiple myeloma: spotlight review. Leukemia 2009;23:2210-2221.

19. Boyd KD, Ross FM, Chiecchio L, Dagrada GP, Konn ZJ, Tapper WJ, Walker BA, Wardell CP, Gregory WM, Szubert AJ, Bell SE, Child JA, Jackson GH Davies FE, Morgan GJ; NCRI Haematology Oncology Studies Group. A novel prognostic model in myeloma based on co-segregating adverse FISH lesions and the ISS: analysis of patients treated in the MRC Myeloma IX trial. Leukemia 2012;26:349-355.

20. Teoh PJ, Chung TH, Sebastian S, Choo SN, Yan J, Ng SB, Fonseca R, Chng WJ. p53 haploinsufficiency and functional abnormalities in multiple myeloma. Leukemia 2014;28:2066-2074.

21. Chng WJ, Price-Troska T, Gonzalez-Paz N, Van Wier S, Jacobus S, Blood E, Henderson K, Oken M, Van Ness B, Greipp P, Rajkumar SV, Fonseca R. Clinical significance of TP53 mutation in myeloma. Leukemia 2007;21:582-584.

22. Lodé $L$, Eveillard $M$, Trichet $V$, Soussi $T$, Wuillème $S$, Richebourg $S$, Magrangeas $F$, Ifrah N, Campion L, Traullé C, Guilhot F, Caillot D, Marit G, Mathiot C, Facon T, Attal M, Harousseau JL, Moreau P, Minvielle S, AvetLoiseau H. Mutations in TP53 are exclusively associated with del(17p) in multiple myeloma. Haematologica 2010;95:1973-1976.

23. Boyd KD, Ross FM, Tapper WJ, Chiecchio L, Dagrada G, Konn ZJ, Gonzalez D, Walker BA, Hockley SL, Wardell CP, Gregory WM, Child JA, Jackson GH, Davies FE, Morgan GJ; NCRI Haematology Oncology Studies Group. The clinical impact and molecular biology of del(17p) in multiple myeloma treated with conventional or thalidomide-based therapy. Genes Chromosomes Cancer $2011 ; 50: 765-774$.

24. Fonseca R, Blood E, Rue M, Harrington D, Oken MM, Kyle RA, Dewald GW, Van Ness B, Van Wier SA, Henderson KJ, Bailey RJ, Greipp PR. Clinical and biologic implications of recurrent genomic aberrations in myeloma. Blood 2003;101:4569-4575.

25. Chiecchio L, Protheroe RK, Ibrahim AH, Cheung KL, Rudduck C, Dagrada GP, Cabanas ED, Parker T, Nightingale M, Wechalekar A, Orchard KH, Harrison CJ, Cross NC, Morgan GJ, Ross FM. Deletion of chromosome 13 detected by conventional cytogenetics is a critical prognostic factor in myeloma. Leukemia 2006;20:1610-1617.

26. Gutiérrez NC, Castellanos MV, Martín ML, Mateos MV, Hernández JM, Fernández M, Carrera D, Rosiñol L, Ribera JM, Ojanguren JM, Palomera L, Gardella S, Escoda L, Hernández-Boluda JC, Bello JL, de la Rubia J, Lahuerta JJ, San Miguel JF; GEM/PETHEMA Spanish Group. Prognostic and biological implications of genetic abnormalities in multiple myeloma undergoing autologous stem cell transplantation: $\mathrm{t}(4 ; 14)$ is the most relevant adverse prognostic factor, whereas RB deletion as a unique abnormality is not associated with adverse prognosis. Leukemia 2007;21:143-150.

27. Bergsagel PL, KuehI WM. Chromosome translocations in multiple myeloma. Oncogene $2001 ; 20: 5611-5622$.

28. Sonneveld P, Avet-Loiseau $H$, Lonial $S$, Usmani $S$, Siegel D, Anderson KC, Chng WJ, Moreau P, Attal M, Kyle RA, Caers J, Hillengass J, San Miguel J, van de Donk NW, Einsele H, Bladé J, Durie BG, Goldschmidt H, Mateos MV, Palumbo A, Orlowski R. Treatment of multiple myeloma with high-risk cytogenetics: a consensus of the International Myeloma Working Group. Blood 2016;127:2955-2962.

29. Avet-Loiseau $H$, Moreau $P$, Mathiot $C$, Charbonnel C, Facon T, Attal M, Hulin C, Marit G, Minvielle S, Harousseau J; Intergroupe Francophone du Myélome. Use of bortezomib to overcome the poor prognosis of $t(4 ; 14)$, but not del(17p), in young patients with newly diagnosed multiple myeloma. J Clin Oncol 2010;28(15 Suppl):8113. 
30. Shaughnessy JD Jr, Zhan $F$, Burington BE, Huang $Y$, Colla $S$, Hanamura I, Stewart JP, Kordsmeier B, Randolph C, Williams DR, Xiao Y, Xu H, Epstein J, Anaissie E, Krishna SG, Cottler-Fox M, Hollmig K, Mohiuddin A, PinedaRoman $M$, Tricot G, van Rhee F, Sawyer J, Alsayed $Y$, Walker R, Zangari $M$, Crowley J, Barlogie B. A validated gene expression model of high-risk multiple myeloma is defined by deregulated expression of genes mapping to chromosome 1. Blood 2007;109:2276-2284.

31. Decaux 0 , Lodé $L$, Magrangeas $F$, Charbonnel $C$, Gouraud $W$, Jézéquel $P$, Attal M, Harousseau JL, Moreau P, Bataille R, Campion L, Avet-Loiseau H,
Minvielle S; Intergroupe Francophone du Myélome. Prediction of survival in multiple myeloma based on gene expression profiles reveals cell cycle and chromosomal instability signatures in high-risk patients and hyperdiploid signatures in low-risk patients: a study of the Intergroupe Francophone du Myélome. J Clin Oncol 2008;26:4798-4805.

32. Kuiper $R$, Broyl $A$, de Knegt $Y$, van Vliet $M H$, van Beers EH, van der Holt $B$, el Jarari L, Mulligan G, Gregory W, Morgan G, Goldschmidt H, Lokhorst HM, van Duin M, Sonneveld P. A gene expression signature for high-risk multiple myeloma. Leukemia 2012;26:2406-2413. 